\title{
Transfer Pricing as Tax Planning Strategy for Multinational Companies in Indonesia
}

\author{
Robin (BC202120113), Vika Shaumi Nurjannah (BC202120180) \\ DOI: 10.29322/IJSRP.11.07.2021.p11579 \\ http://dx.doi.org/10.29322/IJSRP.11.07.2021.p11579
}

\begin{abstract}
This study aims to analyze on transfer pricing as tax planning for multinational companies in Indonesia. As a result of transactions from transfer pricing, The implementation of transfer pricing tends to be done to avoid tax. However, if transfer pricing is categorized as tax evasion then the multinational company is considered to be a tax crime and will be subject to tax criminal sanctions in accordance with the provisions apply. The important thing that must remain concern in transfer pricing is the company's ability to enter into external competition so that the determination of transfer pricing must be calculated carefully.
\end{abstract}

Keywords- Transfer pricing, multinational companies, Indonesia

\section{INTRODUCTION}

Tax planning is a means that allows for planning the taxes that will be paid so that they don't happen excess in paying taxes. Tax Planning does not mean as efforts to avoid taxes because if so, it is clearly contrary to applicable tax laws. Own tax planning at the forefront of tax management. Tax management can defined as the management of the company so that the obligation to fulfill tax obligations can be carried out properly and properly, with the amount of tax that can be reduced as low as possible to get expected profit without elements of violations that can later be result in penalties or fines. Thus the goal tax management is to make tax efficiency efforts to achieve rational profit and fulfill its tax obligations correctly.

Tax planning for a multinational operation is a very complex job, but on the other hand contains aspects that are vital to international business. As known,taxes have an impact on investment decisions abroad, financial structure, determination of the amount of capital costs, currency management foreign exchange, working capital management and financial control.

International trade relations are increasingly wide open and more extensive at this time, causing also the need for the provisions of the tax laws governing international transaction issues. Along with several upgrades tax rates in some countries, there are also increasing ways international tax avoidance, which includes: On the other hand, there are several areas in this world which are called paradise tax havens that accommodate moving funds internationally (internationally mobile funds). In addition, because Multinational companies have a decisive position in terms of what principle will he use which is certainly beneficial for group, then the Multinational Company may use prices that deviate from generally accepted prices. The multinational company can use transfer pricing that is lower than arm's length price, for the purpose of streamline the tax burden or use a higher price of the arm's length price for certain purposes.

Tax Planning is the first step in management tax. Errors in tax planning can be fatal, because consequences borne by the company can accumulate. Planning Tax is a structuring action related to potential tax consequences, the emphasis on controlling every transaction that has tax consequences. The purpose is how these controls can streamline the amount of tax which will be transferred to the government, through what is referred to as tax avoidance and not tax smuggling (tax evasion) which is a fiscal crime that will not be tolerated.

From discussion above, it can be seen that tax planning through Tax evasion is the only legal way that can taken by taxpayers in order to streamline payments the tax. In its own implementation, it really depends to managers, to what extent are these managers constantly on the lookout for tax-saving alternatives to every action he will take (Mohammad Zain, 2003).

Tax planning for a multinational operation is a very complex job, but on the other hand contains aspects that are vital to international business. As known, taxes have an impact on investment decisions abroad, financial structure, determination of cost of capital, currency management foreign exchange, working capital management and financial control.

In order to evaluate trade policies and past effectiveness cross international capital, is less efficient if only focused narrowly on tariffs, quotas and non-tax subsidies, because the tax factor also plays a significant role in the evaluation of the policy. Tax policy is sometimes very instrumental in making tax decisions regarding the investment and financing of companies that will make investments abroad. 
Although basically the system taxes around the world are almost the same as each other, however In some respects there are differences regarding various dimensions, such as:

1. marginal rates that differ essentially from the $0 \%$ rate in countries so-called tax havens (tax-haven countries), until $60 \%$ tariff in certain countries known as country high-tax countries.

2. income definitions differ dramatically from country to country with other countries

3. the notion of income that is exempt from imposition tax

4. taxpayers are only taxed from domestic income or including foreign income.

While multinational companies for their operations abroad, sometimes have to set up several branches or representatives companies in several countries that are subject to regulatory requirements national tax laws. In some countries, among others such as the United States, Britain, Japan, and Indonesia adhere to the meaning of income, both domestic and international income foreign income (global tax system -worldwide income), moderate France, Switzerland, Hong Kong, Belgium and the Netherlands do not charge taxes on the company's activities outside its country, which is referred to as territorial tax system (regional income).

Most of the transactions that occur between members of the Company group These multinationals can be categorized into several transactions, such as sales of goods and services, licenses, patents and know-how, guarantees debt and so on. Prices charged to transactions these, do not need to be the same as the prices prevailing in the free market. Because Multinational Companies have a position that determine in terms of what principle it will use which of course profitable for the group, then it could be a multinational company it uses a price that deviates from the prevailing price general. The price deviation in question is a deviation from the price the so-called "arm's length price" which is usually applicable and agreed by both parties who make transactions on the goods the same and under the same conditions, if the company have no special relationship (unrelated parties).

The multinational company can use transfer pricing that is lower than arm's length price, for the purpose of streamline its tax burden or use prices higher than the arm's length price for certain purposes. Nevertheless, what whatever the reason, if there is an inter-group transaction that deviates from the arm's length price, whether the price is lower or higher. This is allegedly an attempt to shift the company's profits from one company to another group to group and this also means that the tax payable is the two groups involved will experience changes (Bernard, Jensen, \& Schott, 2006).

In terms of the interests of Multinational Companies, in order to organizing transactions between units within the group, is a problem transfer pricing is an issue that must be considered, with a note that the actual price adjustment with the price free market in order to determine the taxable income reasonable need not to pay attention to obligations under existing treaties that must be complied with by countries that concerned to meet certain prices or purposes from the country concerned to reduce the amount of tax owed.

The most frequently discussed issues in planning Multinational corporate tax regarding taxation issues on income in different tax jurisdictions. Troubleshooting this usually done through a Double Taxation Avoidance Agreement, which, aims to prevent the imposition of double taxation on income multinational companies by breaking up income and costs allocated across the various tax jurisdictions. Prevention the double taxation can actually be avoided if:

1. the imposition of tax on his income is only imposed on income in only one country

2. the provisions of tax laws and regulations allow there is a kind of tax credit that can be calculated with taxes owed.

However, the double taxation can be reduced by credit tax credits, tax treaties, tax havens, tax exemptions and the principle of deferral (the deferral principle). What is meant by:

1. Tax credit, allows taxpayers to reduce the amount of tax payable/paid overseas from the amount of tax owed based on the calculation of the provisions of the legislation domestic taxation. This reduction is a direct reduction of the amount of tax payable, so that in certain cases reduce double taxation.

2. Tax treaty, regulates any matters between the countries concerned from an income that is taxed and not taxed by the authority of the country in which the income is received or earned.

3. Tax haven, is a country where the income tax rate very low or no taxation at all income. In general, this tax haven country is used by company for investment or income transfer which tax low or no tax levied on that income. Tax haven countries are also used by Multinational companies to shift income from the country with high tax rates to this country, through transfer pricing.

4. Tax exemption, allows certain companies do not need pay income tax on a certain income as well.

5. The deferral principle, is a kind of tax deferral such that such a way that the parent companies will not taxed on foreign earnings up to the company parent is really accepted.

In fact, it is not only the problem of double taxation that must be considered in international tax matters for companies Multinational, but also that the tax will have an impact too to management decisions, where to invest, how to market their products, what form of business suitable both commercial and fiscal, when and how tight forex traffic or return of profit after tax, how and in what way the financing will be carried out, including Transfer Pricing problem. 
This will be more evident in the next discussion which shows how transfer pricing is chosen for goods and services transferred across national borders, has a considerable impact adequate for international tax debt. Likewise the use of the state tax havens and fax treaties by multinational companies in order to do tax evasion

Based on the description above and as far as literature searches have been carried out, this study aims to analyze on tax system in Indonesia in terms of transfer pricing transactions carried out by multinational companies with related party companies from abroad.

\section{LITERATURE REVIEW}

Transfer pricing is a classic issue in international transactions' from the government side, transfer pricing can result in reduced or loss of potential revenue of a country, especially those originating from taxes, because multinational companies tend to shift their tax obligations from countries that have tax rates that are (high tax countries) to countries that apply tax rates low (low tax countries). Ironically, this problem can't be solved unilaterally by each country but must be done unilaterally together (multilateral cooperation).

On the other hand, from a business perspective, companies tend to minimize costs (cost efficiency) including corporate income tax. For global companies (eg multinational corporations), transfer pricing is one of the effective strategy to win the competition in fighting over limited resources.

Transfer pricing in decentralized companies, generally measured by using the value of the product (either in the form of goods or services) at the time of delivery of goods or services from the profit center to responsibility centers other within the company. On the other hand, transfer pricing can be compared with the market price if transactions occur between the company and other third parties that are not there is a special relationship (Septarini, 2012).

In multinational companies that use profit centers, transfer pricing will always occur, which are generally divided on "the market-based price" and "the cost-based price". The use of market-based transfer pricing is relatively sufficient objective when compared to the results of the seller's negotiating skills or the buyer at the sales responsibility center or the buyer's responsibility. Most company managers expect that profit responsibility centers should be able to use a price close to the transfer pricing known as the "arm's length price" assuming that these responsibility centers as an independent business.

In some situations, where there is no transfer pricing reliable market-based that will be used as a basis determination of transfer pricing, then cost-based transfer pricing will used (Septriadi, 2014). Where possible such fee-based transfer pricing, should be standard costs. But when the price is used actual cost, the purchasing responsibility center will less incentive to control efficiency, because every increase in prices that occur will automatically be added by the center responsibility for transfer pricing is meant for this, managers usually will do the specification of the calculation of the cost and how much profit margin to be added to the transfer pricing, with the goal of reducing the opportunity to argue. The trick is that managers should be very careful and consider all factors determine the calculation of costs and profits. For example, specifically for the calculation of transfer pricing per unit in the short term (short term per-unit costs) should be distinguished from transfer pricing per unit long-term (long-term per-unit cost). Also questionable, are all cost elements normally included in the calculation selling price or full cost (full cost) that must be included in the determine internal transfer pricing, as well as disputes or price mismatch accompanied by the buyers' "emotions" can occur in market conditions that corner sellers to reduce its profit margin to a lower price than the set back in the transfer pricing calculation specification (Setiawan, 2016). For example, the determination of transfer pricing is strongly influenced by the law domestic country of a country, especially if the center seller responsibility and buyer responsibility center are in different countries (e.g. one of the car components

GM based in the United States is produced by the company assembly in Europe). These domestic laws are usually aimed at to prevent any profit shifting from the state high-tax country to a low-tax country by manipulating transfer pricing.

Both market-based transfer pricing and cost-based transfer pricing not reaching a price agreement between the parties, it is not uncommon for transfer pricing to be negotiated between buyers and sellers beyond the referenced price or based on application of a predetermined cost formula. Also because there is a desire on the part of the seller to implement a transfer policy normal company pricing. For example, center sales liability may be selling below price normal market than the company loses at all, as long as purchasing responsibility centers excel at making low-priced purchases at any given time. In such a case, the parties will negotiate.

If the responsibility centers do not have full authority in determining transfer pricing or between parties there is no balanced bargaining authority, for example one party has full authority to determine transfer pricing while the other party others do not have full authority to determine transfer pricing, then the results will not provide transfer pricing negotiations that adequate. If there is a condition, where the prospective center responsibility for sales that do not have adequate resources worry - free can not invest anywhere or prospective purchasing responsibility center that can't refuse the work assigned to him, then in this kind of situation

An arbitration mechanism is needed to solve the transfer problem debatable pricing. Both the negotiation mechanism and the mechanism arbitration sometimes takes quite a long time.

In a business world characterized by high income tax rates, varies from country to country, for the multinational companies whose operations cover several countries often using income tax as one of the elements that can optimize the profits it earns, by maximizing 
income in a low-tax country and minimize income in a high-tax country. On the other hand, some countries see that the actions of minimize the tax burden by operating multinational companies with such an international scope, it is likely to be interfere with its tax revenues, is currently trying to include in the income tax law, the provisions relating to the transfer pricing in question, including the issue of transfer of profits from the subsidiary company to the parent company (Setiawan, 2014).

Another problem that arises from transfer pricing is when transfer pricing decisions made by management are based on solely on tax considerations (tax purpose). In perspective taxation, transfer pricing is defined as the price charged by a company for goods, services or intangible properties for subsidiary or other related companies. Since the prices are not negotiated in a free, open market they may deviate from prices agreed upon by non-related trading partners in comparable transactions under circumstances. (John Hutagaol, Journal Taxation August, 2002).

The tax rates that apply in each country vary will encourage management to relocate their income (revenues) to countries that apply relatively low tax rates (low tax countries) and conversely charge more business costs to countries that apply relatively high tax rates (high tax) countries) (Hilton, p. 881). A transfer pricing strategy that aims to doing tax avoidance will be very detrimental countries that are high tax countries because these countries lost potential tax revenue that should have been obtained problem transfer pricing will be even worse if it is intended to tax evasion, which is classified as a tax crime. An act of transfer pricing is categorized as a tax avoidance or tax evasion is very thin difference.

The tax implications of transfer pricing arrangements can be seen in the following illustration: In order to have a transfer pricing adjustment between the tax authorities and the taxpayers, with regard to "arm's length price", also developed in the provisions of laws and regulations taxation a model similar to the "transfer" model negotiation pricing and transfer pricing arbitration" above, with the introduction of the "transfer pricing agreement - advance pricing agreement (APA)" model as seen in Article 18 of Law no. 7 of 1983 concerning Income Tax as has been several times last amended by Law no. 17 of 2000.

\section{RESEARCH METHODLOGY}

This research is the discovery and assembly of arthritis related to legal issues; and the field of study concerned drafting an effective authority that addresses such legal questions (Bryan, 1999). Jurisprudence is normative. Research methods include approaches, legal determination of sources and critical analysis of sources through exploration, investigation and interpretation.

This research is a qualitative research that refers to the legal norms contained in the articles of association and judicial decisions related to the problem. The steps for collecting legal sources include reading, studying, citing, comparing and connecting legal and literary sources, so that they become a single unit that is easy to work with.

\section{DISCUSSION AND FINDINGS}

Transfer pricing agreements (Advanced Pricing Agreement or APA) are agreement between the Taxpayer and the Director General of Taxes regarding the fair selling price of the products it produces to parties who have a special relationship with him. Destination holding APA is to reduce the occurrence of practice misuse of transfer pricing by multinational companies approval between the Taxpayer and the Director General of Taxes may includes several things, including the selling price of the products produced amount of royalties and others, depending on the agreement. Profit from what besides providing legal certainty and ease of calculation tax, tax officer does not need to make corrections to the selling price and profit products sold by Taxpayers to companies in the same group. APA can be unilateral, which is an agreement between the Directors General of Taxes with Taxpayers or bilaterally, namely an agreement between Director General of Taxes with other country's tax authorities concerning Taxpayers residing in their jurisdiction (Hiemann \& Stefan, 2012).

Prior to the statement of transfer pricing issues by using "transfer pricing-advance pricing agreement" as referred to in article 18 paragraph (3a) above, the Director General of Taxes has issued Circular Letter NO. SE-04/PJ.7/1993 dated March 9 1993 which is considered still relevant to the issue of transfer pricing (except advance pricing agreement) which basically contains the following:

as follows: Universally, transactions between Taxpayers that have a special relationship is known as transfer pricing. This may result in a transfer of income or the basis for the imposition of taxes and/or fees from one Taxpayer to another taxes, which can be engineered to reduce the total amount of tax owed to the taxpayer. Taxpayers who have the special relationship.

It should be realized that with the development of the business world, rapidly, which is often transnational and the introduction of new products and business methods that were not previously recognized in the field of business (for example in finance and banking), then the forms and variations of transfers pricing can be unlimited.

The transfer pricing problem in the tax treaty agreement starts from Article 9 of the UN Model which regulates companies that have special relationship, namely between the parent company domiciled in one of the one country with subsidiaries/branches domiciled in the country other. 
Paragraph 1 of Article I of the UN Model, mentions the granting of authority to one of the countries to verify the transactions between related parties, such as between the parent company and its subsidiary subsidiaries, as long as does not show the arm's length price according to the market or In other words, verification will not be carried out, if the transaction already based on fair prices.

Furthermore, paragraph 2 also stipulates that if a transaction occurs between two parties who have a special relationship, and the transaction does not use the arm's length price, one of the parties to approval can make adjustments that should also be followed by other state parties. If the adjustment problem is not followed by other state parties (correlative adjustment). then it will happen economic double taxation (imposition of double taxation on the same income by different people/countries) If for example there is a tax treaty agreement between Country A and country B, it must be remembered that adjustment made by country A in the form of an increase in its tax base does not automatically have to be followed by country B, but it will make adjustments if it shows a significant profit based on arm's length.

The next problem, is determining how to adjust it must be implemented. There are two options for this: For example, company A in country A makes a transaction with company B (still in the same group) in country B. Adjustments have been made by A, because the transaction is not based on the arm's length price. Steps that can be taken by B in terms of correlative adjustment is by calculating and re-establishing the amount of tax owed, or done through a tax credit mechanism as regulated in articles of the tax treaty model. In this case B may credit the amount of tax paid by A, as a result of adjustments made in country A

Basically the correlative adjustment does not guarantee no the occurrence of profit shifting between companies in the group the same thing, because this could have been done in another way, namely through the payment of dividends, royalty or other payments and necessary It is known that paragraph 2 does not prevent a country from committing correlative adjustment throughout the national law allows doing that.

From the point of view of multinational companies, transfer pricing is a tool to mobilize profits for the benefit of the company themselves, while on the other hand the tax authorities always want transactions that occur between companies within the same group, are executed at arm's middle price in accordance with the principles adopted by the OECD. The basis for considering the selection of this method is: the principle places companies from one group in the same conditions as an independent company so that eliminate both favorable and unfavorable factors harmful.

\section{CONCLUSION}

Policies in determining transfer pricing are important because it is related to the performance appraisal of each subsidiary. The setting of high transfer pricing will generate profits in the selling subsidiary instead becomes a cost to the subsidiary buyer. But in the end the real profit will appear in overall company profit. The important thing that must remain concern in transfer pricing is the company's ability to enter into external competition so that the determination of transfer pricing must be calculated carefully.

The effect of transfer pricing must also be seen from the side of the tax law so that the determination of transfer pricing does not increase the tax burden that shouldn't have happened or should still be possible to minimized. For multinational companies, transfer pricing is done with the aim of obtaining global tax savings by relocate its global income to low tax countries and shift larger amounts of costs in big tax counts. The implementation of transfer pricing tends to be done to avoid tax. However, if transfer pricing is categorized as tax evasion then the multinational company is considered to be a tax crime and will be subject to tax criminal sanctions in accordance with the provisions apply.

In order to have a transfer pricing match between the authorities taxes with taxpayers, regarding the "arm's length price", also developed in the provisions of laws and regulations taxation a model similar to the "transfer pricing" model negotiation and transfer pricing arbitration" above, with the introduction of the "transfer pricing agreement - advance pricing" model agreement (APA)" as seen in Article 18 of Law no. 7 of 1983 concerning Income Tax as has been several times last amended by Law no. 17 of 2000. Even though Thus, in practice, not all taxpayers can use APA program because the procedure is quite expensive and time consuming, so for small taxpayers this becomes difficult. Therefore APA procedures are usually only helpful in cases of transfer pricing value is quite large.

\section{REFERENCES}

[1] Bernard, A. B., Jensen, J. B., \& Schott, P. K. (2006). Transfer pricing by US-based multinational firms (No. w12493). National Bureau of Economic Research.

[2] Hiemann, M., Stefan, R. (2012), In: Wolfang, S., Konrad, K.A., editors. Fundamental of International Transfer Pricing in Law and Economic. London: Springer.

[3] John Hutagoal, SE, M.Acc, Mec. Kapita Selekta Akuntansi Pajak. Edisi Pertama. Jakarta: PT Kharisma, 2003

[4] Mohammad Zain. (2003). Manajemen Perpajakan. Edisi Pertama. Jakarta: Penerbit Salemba Empat.

[5] Septarini, N. (2012), Regulasi dan praktik transfer pricing di Indonesia dan negara maju. Jurnal Akutansi Unesa, 1(1), 12.

[6] Septriadi, D. (2014), Transfer pricing: Saat ini dan masa mendatang. Inside Tax, 18, 76.

[7] Setiawan, D.A. (2016), Penentuan Harga Transfer Pricing Atas Transaksi International Dari Perspektif Perpajakan Indonesia. Available from: http://www.portal.kopertis3.or.id/handle/123456789/2016. [Last accessed on 2016 Jul 01].

[8] Setiawan, H. (2014), Transfer Pricing dan Risikonya Terhadap Penerimaan Negara. Available from: http://www. kemenku.go.id.Sites/default/files/2014_kajian_pprf_TransferPricingdanRisikonyaTerhadapPenerimaanNegara.pdf. [Last accessed on 2017 Feb 01]. 
International Journal of Scientific and Research Publications, Volume 11, Issue 7, July 2021

First Author - Robin, robin_1025va@hotmail.com.

AUTHORS

Second Author - Vika Shaumi Nurjannah.

Correspondence Author - Robin, robin_1025va@hotmail,com, 628127030360. 